\title{
Anabases
}

ANABASES Traditions et réceptions de l'Antiquité

13 | 2011

Varia

\section{Elias Bickerman and Hans (Yohanan) Lewy : The Story of a Friendship}

\section{Albert I. Baumgarten}

\section{(2) OpenEdition}

12 Journals

\section{Electronic version}

URL: http://journals.openedition.org/anabases/1764

DOI: 10.4000/anabases.1764

ISSN: 2256-9421

\section{Publisher}

E.R.A.S.M.E.

\section{Printed version}

Date of publication: 1 March 2011

Number of pages: 95-118

ISSN: 1774-4296

\section{Electronic reference}

Albert I. Baumgarten, «Elias Bickerman and Hans (Yohanan) Lewy : The Story of a Friendship », Anabases [Online], 13 | 2011, Online since 01 March 2014, connection on 21 October 2019. URL http://journals.openedition.org/anabases/1764 ; DOI : 10.4000/anabases.1764

This text was automatically generated on 21 October 2019

(c) Anabases 


\title{
Elias Bickerman and Hans (Yohanan) Lewy : The Story of a Friendship*
}

\author{
Albert I. Baumgarten
}

In Honor of Joseph Mélèze Modrzejewski

of Paris, who recently celebrated his $80^{\text {th }}$

birthday,

a dear friend of Elias Bickerman

1 Elias Bickerman (1897-1981) ${ }^{1}$ and Hans (Yohanan) Lewy (1901-1945) were two of the most outstanding products of the Institut für Altertumskunde of the Friedrich-Wilhelm University in Berlin, during its period of glory, the Weimar years. Each scholar, in his own way, embodied and advanced the integrative study of all aspects of Mediterranean antiquity that was the hallmark of the Institut für Altertumskunde. As one can learn from archival documents, they were also among each other's closest friends. For example, Elias Bickerman never wrote about personal matters to his different correspondents. His St. Petersburg teacher and mentor for life, Michael Rostovtzeff (1870-1952), noted that when he corresponded with Bickerman, "he never speaks about his family affairs". Thus, while Rostovtzeff knew that Bickerman had no children when he had last seen him in 1937, he did not know if any had been born up until 1940, when Rostovtzeff wrote the letter just cited ${ }^{2}$. It was, however, a mark of his special friendship with Hans Lewy that Bickerman wrote to Lewy, after arriving in the USA in August 1942, congratulating Lewy on his marriage and wishing Lewy the best, in his capacity as "an old and truly dear friend". As to his own circumstances, Bickerman added that he and his wife were safe in the USA, while his brother and family were in London, and that his father had died in Nice in January 1942. He concluded the letter by offering to visit Lewy's mother, who was then in NY, and by inviting Lewy and his wife to visit Mrs. Bickerman and himself in Paris, when the Bickerman couple returned there after the war (as Bickerman then expected and intended), as Lewy had visited them there in $1938^{3}$. 
2 When Lewy took ill suddenly and then died on July 22, 1945, Bickerman wrote to Mrs. Lewy as soon as he learned of his friend's death, describing Lewy as "an old, old and dear, very dear friend". He concluded the letter by remarking:

I shall not try to alleviate your grief by consolatory words. But perhaps your heart will be relieved when you hear that not you alone are grieved, that Hans' friends, and I among them, will not stop to love him as before, remember him and think of him. And I have heard that sorrow partaken with others is easier to bear"

3 In an academic context, Bickerman noted Lewy's help with an early article, writing: Darauf hat mich mein Freund Dr. Hans Lewy in Berlin hingewiesen, der auch sonst durch Rat und Tat diese Arbeit kräftig förderte ${ }^{5}$. Bickerman also acknowledged Lewy's enthusiastic support and many improvements with Der Gott der Makkabäer: Das Buch verdankt ihm reiche Anregung und mannigfache Verbesserung ${ }^{6}$. Lewy's role in this case was not limited to the contents and arguments of the book. At the request of the publisher, Schocken Verlag, Lewy corrected and improved Bickerman's German. A note in the Schocken archive indicated that Bickerman's Gott was: Zur Zeit zur Stilrevision bei Dr. Hans Lewy, Jerusalem ${ }^{7}$.

4 Lewy's major scholarly project, not yet finished at the time of his death, was a comprehensive work on Jews and Judaism in Greek and Latin literature, a thoroughgoing revision and expansion of $\mathrm{T}$. Reinach, Textes d'auteurs grecs et romains relatifs au judaïsme, published in 1895. After Lewy's death, Mrs. Lewy wrote to Bickerman asking if he would complete his friend's unfinished research. Bickerman recommended that someone else be found. He had obligations that would keep him busy for the next three years, after which he might return to Paris: "In this situation, it would be selfish to grab at Hans's materials while I cannot sit down to publish his work.".

5 Finally, writing to Martin Hengel (1926-2009), when reviewing his collected papers on Jewish and Christian topics that he was preparing for publication as Studies in Jewish and Christian History, Bickerman expressed his high evaluation of Lewy and his abilities, noting his own ignorance of Hebrew, the Talmud, Akkadian, or other oriental languages. Bickerman insisted that he saw his limitations: "As a matter of fact, my only advantage is longevity. By some chance, I survived while better ones disappeared: for instance Hans Lewy (emphasis mine) $)^{9}$."

6 One basis for this friendship was that both Bickerman and Lewy faced career difficulties in Berlin, perhaps because they were Jewish. In Bickerman's case, after a very successful doctorate, he did not pass on his first try at Habilitation. The formal reasons were the disappointing nature of the Habilitationsschrift and its sloppy presentation. However, this failure may have also had something to do with Bickerman being perceived as an "uppity" foreign Jew, who needed to be taught a lesson. Another possibility is that Bickerman may have irked Eduard Meyer (1855-1930) by accepting a subvention from the Notgemeinschaft der Deutschen Wissenschaft, in which Meyer played a leading role, while refusing Meyer's offer to help obtain German citizenship ${ }^{10}$.

7 In Lewy's case, his doctorate was not that well received. Werner Jaeger (1888-1961) and Ulrich v. Wilamowitz-Moellendorff (1848-1931), the two readers, were not convinced that Lewy had sufficiently proven his main conclusions. They marked the thesis only as idoneum, a passing grade, but not one of distinction ${ }^{11}$. At Lewy's oral doctoral exam, 
Ulrich Wilcken (1862-1944) was disappointed with Lewy's replies on Roman History, concerning the careers of Sulla and Julius Caesar, marking Lewy as genügend, satisfactory. The overall grade was only cum laude ${ }^{12}$.

8 Habilitation, in July of 1933, was explicitly complicated because Lewy was Jewish. In a Lebenslauf on deposit in the Lewy Archive, written sometime in the 1930s, as Lewy described himself as not yet married, when Lewy was already teaching in Jerusalem, he wrote that:

Juli 1933 Habilitation an der Philosophischen Fakultät d. Berliner Universität für das neueingerichtete Lehrfach Oriens Christianus. Habilitationsschrift: "Eine jüdischhellenistische Rede über den Propheten Jona in armenischer Überlieferung." Verlust der venia legendi infolge Beamtengesetzes.

This summary was not entirely accurate. At Lewy's Probevorlesung, on July 10, 1933, the following decision was taken:

Es wird beschlossen, Herrn Dr. Lewy die Venia legendi für "orientalische Kirchensprachen" nicht zu erteilen, ihm vielmehr mündlich und schriftlich folgendes zu eröffnen:

Die Fakultät stellt auf Grund der Habilitationsschrift, des Probevortrags und des Kolloquiums fest, dass Herr Dr. Hans Lewy den wissenschaftlichen Anforderungen, die die Fakultät an ihre Habilitanden stellt, in hervorragenden Masse entspricht. Sie ist aber durch die auch auf Habilitanden anzuwendenden Bestimmungen des $\S 3$ des Gesetzes zur Wiederherstellung des Berufsbeamtentums gehindert, die Venia legendi zu erteilen ${ }^{13}$.

10 In fact, only a few days earlier, on July 7, 1933, the faculty was instructed by the Minister of Education, Bernhard Rust (1883-1945), to simply terminate the Habilitation procedures of all Jewish candidates, since they could not be appointed as a result of Nazi legislation ${ }^{14}$. When Lewy appeared before the Faculty Colloquium on July 10, this was an act of defiance, and the decision taken had an element of protest. Nevertheless, the Faculty was powerless. Formally, Lewy passed Habilitation, but was not granted the venia legendi. Effectively, however, he neither passed nor failed: he was simply disqualified. Indeed, the HU archive maintains a list of those who attempted Habilitation. That list is divided into those who passed and those who failed. As a consequence of the decision taken at his Probevorlesung just cited, Lewy appears in neither list.

11 This outcome prompted Eduard Norden (1868-1941), whose role as Lewy's teacher will be discussed further below, and who was present on July 10,1933, to write the following letter of recommendation, dated July 14, 1933, which he gave Lewy, preserved in the Lewy Archive, and apparently intended for the authorities at the Hebrew University:

Gutachten

Herr Dr. Hans Lewy ist mir seit Jahren sehr genau bekannt. Während seiner Studienzeit auf der Berliner Universität war er mein persönlicher Schüler, und er gehörte zu den begabtesten, die ich gehabt habe. Er zog meine Aufmerksamkeit durch die Vielseitigkeit seiner Interessen auf sich; so zeigte er sich auf lateinischen Arbeitsgebiet, wie die Prüfung im Doctorexamen ergab ${ }^{15}$, als einen tüchtigen Kenner des Lukretius, und sein eindringendes Verständnis des Schriften des Ambrosius erwies er in einer Abhandlung, die von mir der Berliner Akademie der Wissenschaften vorgelegt wurde und in deren Schriften erscheinen ist. Nebenher ging seine Beschäftigung auf dem ebenso interessanten wie schwierigen Problem des Jüdischen Hellenismus ${ }^{16}$, insbesondere dem Philonischen Schrifttum, woraus seine Doctordissertation erwuchs, die sich in Gelehrtenkreisen beträchtlicher Beachtung erfreut ${ }^{17}$.

Sein grosses Talent in den beiden klassischen Sprachen sowie seine Neigung zu religionsgeschichtlicher Forschung veranlassten meine Fachkollegen Excellenz $v$. 
Wilamowitz und Prof. Eduard Meyer ${ }^{18}$ sowie mich selbst, Herrn Dr. Lewy, den wir als unseren Schüler und Schützling hoch werteten, sich die Ausbildung als Orientalist (Armenisch, Syrisch, Arabisch) angelegen sein zu lassen, um sich für dringende Aufgaben als klassisch gebildeter Orientalist einzusetzen, eine sehr seltene Doppelbegabung. Mit Unterstützung der Preussischen Akademie der Wissenschaften zu Berlin und der Notgemeinschaft der Deutschen Wissenschaft unternahm er eine Forschungsreise durch den Vorderen Orient und Armenien, um das Material zu einer erstmaligen wissenschaftlichen Ausgabe der armenisch erhaltenen Schriften Philons zu sammeln. Der mündliche Bericht, den er von dieser mit grossen Gefahren verknüpften Reise Herrn v. Wilamowitz erstattete, war dessen letzte Lebensfreude. Der wissenschaftliche Ertrag dieser Reise war überaus gross, er ging über den unmittelbaren Zweck der Philonsausgabe weit hinaus. Daraufhin unternahm er es, sich zur Habilitation als Privatdozent bei der Philosophischen Fakultät der Universität Berlin zu melden, und zwar für das eigens für ihn von der Fakultät geschaffene Lehrgebiet Oriens Christianus mit Einschluss des Jüdischen Hellenismus. Der Erfolg seines Probevortrags und des mit ihm geführten Colloquium war ausgezeichnet. Es lässt sich mit Bestimmtkeit sagen, dass Herr Dr. L. denselben Erfolg gehabt hätte, wenn er sich zur Habilitation in den klassischen Sprachen (Lateinisch und Griechisch) gemeldet haben würde.

Herr Dr. Lewy gilt mit Recht schon jetzt als Gelehrter von Rang. Es sei aber bemerkt, dass mit dem Gelehrtentum sein sehr kultiviertes und vornehmes Menschentum gleichen Schritt hält. Im besten Sinne des Wortes darf er als vir vere humanus bezeichnet werden.

Dr. Eduard Norden

Prof. an der Universität Berlin

Dr. sc. h.c. Cambridge.

Korr. u. auswärt. Mitglied der Ges. d. Wiss.

Wien, Leningrad, Neapel, Mailand, Lund, Upsala u. Krakau

Norden was pulling out all the stops on behalf of Lewy, mentioning his own distinctions and invoking the memory of his now dead colleagues of the highest rank, Wilamowitz and Meyer. Nor was Norden telling the truth, the whole truth and nothing but the truth about what happened at Lewy's Probevortrag. When Norden wrote that Lewy could have passed Habilitation in Greek or Latin he meant to praise Lewy's abilities. However, in a perverse sense, Norden was also correct in terms of the situation of Jews aspiring to an academic career in Nazi Germany: the result would have been the same had Lewy been a candidate for Habilitation in Latin or Greek, not because of his abilities in those subjects, but because Lewy would have been disqualified as a Jew in any field.

In sum, Norden wrote the letter and gave it to Lewy so that Lewy could present it to the authorities at The Hebrew University. Norden's goal, I suggest, was to lay the groundwork for the Hebrew University to rectify the injustice done to Lewy in Berlin as a result of Nazi race laws.

14 And yet, despite the shared career difficulties in Berlin, the Bickerman-Lewy friendship was odd and unlikely. Their temperaments were very different: Bickerman was daring, while Lewy was hesitant, careful, shy, and diffident ${ }^{19}$. Bickerman liked to tell the story of how he and Lewy took a walk one winter day in Berlin. They came to a frozen lake; the ice was sufficiently thick that it was not dangerous to cross, but there was a sign that said that it was forbidden to walk on the ice. Lewy, a good Prussian, took heed of the sign, while Bickerman, the handsome bachelor ${ }^{20}$, dared to walk across the lake, precisely because the sign said not to walk on the ice ${ }^{21}$. While Bickerman and Lewy agreed on one significant ideological point their opposition to communism - they also disagreed about one of the key issues of Jewish life in their times, often a source of dispute that could make friendship impossible ${ }^{22}$. Lewy was a Zionist, who emigrated to Palestine in 1933, while Bickerman was more or less loyal to the anti-Zionist position taken by his father, Joseph Bikerman $(1867-1942)^{23}$. Despite having moderated his views over the years, in his last 
conversation with me, only days before his death, in August 1981, Elias Bickerman lamented the narrow horizons of the Zionist enterprise ${ }^{24}$. In light of their divergent views concerning Zionism, one must look elsewhere for the basis of the Bickerman-Lewy friendship.

The thesis of this article is that one of the most important intellectual foundations of the Bickerman-Lewy friendship was their shared experience as students of Eduard Norden in Berlin, and in their adoption of Norden's approach to the study of antiquity. The study of Classics in Norden's time faced numerous new challenges. Classics, as taught at all levels up to that of the universities, was no longer widely accepted as a canonical discipline, essential for the formation of German national character and identity, as had been the case since the days of Wilhelm von Humboldt (1767-1835) ${ }^{25}$; there were other competitors for this role. Perhaps the most prominent was the circle around Stefan George (1868-1933), the "poet and seer, leader of a tight humorless, selfcongratulatory coterie of young men... king of a secret Germany, a hero looking for heroes in an unheroic time ${ }^{26}$." George and his disciples formed a group with clear sectarian characteristics, in which they were creating a secret center of the world, of which George was the absolute master. Disciples were required to show absolute devotion and sacrifice their personal identity to the total control of The Master. Heretics and traitors were branded and excluded ${ }^{27}$. According to Paul Gérardy (1870-1933), George provided the insight that put an end to His followers' years of hopeless stupid suffering, as He was the only one who still sang the songs of the gods. His devotees gladly offered up all their "brotherly" dreams to dwell in His holy light, in the proud castle of His fellowship ${ }^{28}$.

As one extended example of this loyalty and secrecy, the historian Ernst Kantorowicz (1895-1963) achieved the highest level of success in the USA, appointed to the permanent faculty of the Institute for Advanced Study in Princeton. Nevertheless, he kept a portrait of George on his desk until the end of his life, and wrote to Robert Boehringer (1884-1974) on July 13, 1954:

Weniger vielleicht als andere habe ich oder suche ich, die Gelegenheit, mich zum Thema D.M. $z u$ äussern. Aber es ist kein Tag, an dem ich mir nicht bewusst wäre, dass alles, was ich etwa $z u$ leisten vermag, aus einer Quelle gespeist ist, und dass diese Quelle auch nach über 20 Jahren immer noch sprudelt ${ }^{29}$.

17 True to the ideas he had learned from George, Kantorowicz ordered his body cremated and his ashes scattered in Little Maho, on the U.S. Virgin Islands. He also directed his heirs to destroy his personal papers ${ }^{30}$, a strange step for a professional historian. The guiding principle was, Göttlich ist, wer erscheint, Gott gleich, wer verschwunden bleibt ${ }^{31}$.

George and his followers were merciless in their criticism of the old philology, embodied in the person and contribution of Ulrich von Wilamowitz-Moellendorff ${ }^{32}$. As Gershom Scholem (1897-1982) summarized matters - eulogizing Lewy at a memorial meeting held in Jerusalem on November 18, 1945, several months after Lewy's death ${ }^{33}$ the encounter with the George circle and their academic approach was a key event for young scholars:

This science came from the school of a great poet who also wanted to be a ruler. Disdain for worn out forms and for the true (absolute) or imagined emptiness of (the usual) forms of scientific analysis produced a reaction among those who 
aspired to greatness, who possessed intuition, and who were disciples of an aristocratic philosophy (of life). They intended to disseminate the grand - but very problematic - vision of their master, who was a poetic genius, to (all) branches of knowledge. Their motto was to erect eternal images of greatness, symbolic paradigms of periods and cultures. Truth be told, the conscience of historians and philologists in Germany was apparently not that good. (It was therefore easy for) those who possessed a polished and glowing style, based on unknown profundities of metaphysical understanding, to count those (scholars) whose time was up ${ }^{34}$ as a result of their meaningless worship of research into minutiae ${ }^{35}$. When (Friedrich) Gundolf (1880-1931), (Friedrich) Wolters (1876-1930), (Kurt) Hildebrandt (1881-1966), and (Hermann) Friedmann (1873-1957) and the rest of the George devotees began to view the misera plebs contribuens ${ }^{36}$ of German professors from on high, and announced the arrival of a new science that would investigate symbolic figures, those who were offended and viewed with contempt reacted very little and very mildly ${ }^{37}$. The adherents of the new party quickly conquered the hearts of the best young scholars and some of the most famous university chairs ${ }^{38}$. The intuitive history and philology of George's followers - in which both revolutionary and reactionary objectives were mixed up - had great attractive power, especially for the many young people for whom George's poetry had been the decisive literary experience of their youth... Wilamowitz, the master of Classical Philology in Germany, was one of the primary targets of the attack by the new intuitive science. The choice between the Nietzschean "doves" 39 " of the Georgeans and the old tradition represented by Wilamowit $\mathrm{z}^{40}$ was one of the great emotional decisions that young philologists had to make ${ }^{41}$.

19 Scholem's own interest and attraction to the George circle is explicit from any number of documents. Therefore, although formally he was speaking in memory of Lewy, his comments on the decision scholars needed to make between the Nietzschean "doves" and philology have an autobiographical component ${ }^{42}$. Yet, in the end, Scholem's personal dislike of the George circle is evident throughout this passage, but just in case any reader missed the point he concluded this summary with the comment that many of George's followers became "prophets of the new Baal and kindled a foreign flame in the temple of wisdom", i.e. were devoted Nazis ${ }^{43}$.

Norden would have none of this. For him, Wilamowitz was the bright, shining, central star of the discipline: Princeps philologorum, aquila in nubibus ${ }^{44}$. Norden recognized that Wilamowitz had been the subject of criticism, yet insisted that Wilamowitz was more open than anyone to well founded arguments contradicting his own previous conclusions ${ }^{45}$. Norden maintained that Wilamowitz was intimately connected, in the best possible way, to the contemporary German world in which he lived. His contribution was to ennoble the stock of the German tree with a Greek graft ${ }^{46}$. He was a classical philologist, firmly opposed to the imitative tendencies of classicism (in the pejorative sense of the term) ${ }^{47}$.

21 In his own work, Norden dealt with philological minutiae, "nitpicking" analysis of words, terms, and formulae. However, according to Elias Bickerman's portrait of Norden $^{48}$, the goal of these studies was not to make something of nothing (see above, nn. 35 and 38), but to ask and answer some of the most important and ever-lasting questions about the meaning of western civilization: As a result of Norden's detailed philological research: So führt die Wortuntersuchung zum Erfassen jener uns gerade jetzt so fühlbar nahen Zeit, da das Schauen der Mystik den überspannten Intellektualismus zu überwinden begann ${ }^{49}$. Norden's results could then serve as a counterbalance to what Ernst Troeltsch called: "The peculiarly German inclination to a mixture of mysticism and brutality ${ }^{50}$." Or, as Norden put it, in his inaugural address as Rector, a little bit of 
mysticism might be an antidote to contemporary materialism, but he warned against other forms of mysticism that would lead to magic, occultism, astrology, and an abandonment of personal responsibility (allegiance to a fuehrer, whether George above, n. 27 - or yet another?). The latter sort of mysticism was the enemy of clarity and thought, all that was characteristic of the Greek soul and of its related German counterpart ${ }^{51}$.

As one concrete example of Norden's method and its consequences, according to Bickerman, Norden showed how:

von Wortformeln zu den Gedankenverbindungen vorzudringen, an der Geschichte einer zentralen religiösen Vorstellung: der vom Heiland und von der Heilszeit. Vergil verkündete inmitten des Bürgerkrieges die Geburt des Retters, des Gotteskindes. Die Frömmigkeit des christlichen Mittelalters verehrte darum im römischen Dichter den Vorgänger der Evangelisten. Indem Norden die Formeln und Ausdrücke der antiken Heilserwartung untersucht, kann er zeigen, daß und wie der lateinische Dichter und der jüdische Künder Jesu beide in demselben Flusse der religiösen Hoffnung standen, dessen Quelle Norden in Aegypten wiederfindet und an dem die Menschen schon vier Jahrtausende sich laben ${ }^{52}$.

In accomplishing these achievements, Norden took advantage of the methods of Universalgeschichte, universal history, promoted by Eduard Meyer, which united the study of all the peoples of the ancient Mediterranean world. According to Rostovtzeff, Meyer, while still at school:

formed the project of writing a general history of the ancient world, which he never abandoned, organizing his life accordingly... Meyer's great contribution lies in the fact that he was the first to give a presentation of ancient history as a whole, as a part of Universalgeschichte - not as a generalization based on second-hand information, but as an original contribution built up on a solid and lasting foundation... his was the first real history of the ancient world ${ }^{53}$.

Indeed, Meyer's approach is evident in Norden's inaugural address as Rector. Besides the obvious turn to Greek, Latin, and German sources, Norden appealed to Egyptian literature, the Hebrew Bible, the New Testament, Babylonian sources, and the formulas in an old Nordic Icelandic peace agreement. Norden recognized that he did not have the linguistic competence to draw conclusions concerning sources in all these language ${ }^{54}$, but relied on the assistance of experts ${ }^{55}$. Even when the explicit focus was on Greeks, Romans, and Germans - as in his address on Heldenehrungen, from 1928 Norden noted that there were impressive examples of the phenomenon under consideration outside the limits of his analysis, which he would therefore not discuss in detail in his speech ${ }^{56}$. In defense of his turning to material in languages that he did not know himself, awkward (if not worse) for a philologist who insisted on mastery of Greek and Latin, Norden declared that he was an intellectual vagabond, dependent on knowledge borrowed from others ${ }^{57}$. Yet, Norden hoped that the results, in his case, would justify the risks taken. In the end, I propose that Norden intended to avoid the reproof that he was one of those German professors who conducted extensive research whose results would allow them to take: "A certain pride in the discovery how few of one's inherited ideals one had to give up ${ }^{58}$." The wider basis on which he drew his historical conclusions could help fill the hunger for wholeness, the fear of modernity, and the desperate need for roots and community that characterized the times. Classical scholarship of fairly traditional sort, supplemented by Meyer's Universalgeschichte was supposed to supply a sufficient cultural foundation to cope with the uncertainties of the new age. 

recognized as German. He considered the fact that he was born a Jew a personal disaster ${ }^{59}$. In his popular talks, he always stressed that he shared the German national and cultural heritage: it was ours ${ }^{60}$. As a result, Norden's encounter with Nazism was unusually traumatic and left him a confused and broken man ${ }^{61}$. His conversion to Christianity at age seventeen was of no avail. He had no interest in the return to Judaism widespread among other former Jews after Nazi persecutions began. In his view, too many were becoming Jewish fanatics, newly devoted to a religion that he considered an empty shell, devoid of all meaning. Nor did remarks that came uncomfortably close to support for Hitler, as the strong man who might save Germany, help; Norden had no choice but to fire Jewish assistants. At times, Norden openly acknowledged his Jewish origins. After Norden had departed Berlin for Zurich, one of his students petitioned Hitler, asking that Norden be designated an Aryan. Nazi race laws and public persecution of Jews, by contrast, were clear and explicit ${ }^{62}$. Norden had four Jewish grandparents, who were also practicing Jews ${ }^{63}$. He was forced to leave Berlin for exile in Switzerland, where he died on July 31, 1941.

Elias Bickerman's ways to deal with the cultural and political realities described above represented a continuation of Norden's approach, but with a few significant differences. Like Norden, Bickerman was an old-fashioned philologist who had a strong commitment to universal history. Thanks to having studied with Wilcken at Berlin, Bickerman was devoted to the Urkundenlehre, emphasizing the importance of inscriptions and papyri in writing history: he specialized in diplomatics. Writing to Emilio Gabba (1927-), his friend from Pisa and Pavia, Bickerman commented on the work of the anthropologist-historian, J.-P. Vernant (1914-2007):

I bought the latter's book (Mythe et société) in Paris and wasted FF25. He is now pretentious (Prof. at College de France!) and often speaks as a Marxist, that is repeats Marx's nonsense without any consideration of facts. He almost never refers to Greek inscriptions (unknown to Marx), does not understand numismatics, and has no idea of universal history. But, of course, he is the head of a "school", and consequently pusches (sic) forward his own students in the academic world ${ }^{64}$.

While Bickerman's attitude towards his Jewish identity was complex and not easy to define in conventional terms, it was far from as out-rightly hostile as Norden's. Bickerman opened the Lebenslauf of his Berlin dissertation with the affirmation: Ich bin jüdischer Abstammung und bekenne mich zum mosaischen Glauben ${ }^{65}$. In his scholarly work, he deliberately included the Jews in the scope of his investigations of antiquity. He defied the unspoken reluctance of German-Jewish classicists to write about Jewish topics in antiquity on numerous occasions, already during his Berlin years ${ }^{66}$. However, in his American years, after 1942, when Bickerman turned to the study of ancient Jewish texts in Hebrew and Aramaic, he continued Norden's vagabond approach ${ }^{67}$. Since he never learned Hebrew well as a youngster ${ }^{68}$, and resisted the urging of his friends to do so later in life (see below, page 116), he relied on the assistance of a team of "research assistants", his friends at the Jewish Theological Seminary. These were some of the most distinguished experts of the time. Indeed, if anywhere in his published work Bickerman offered a comment on a Hebrew text based on knowledge beyond that available to all from the most standard translations, one of these friends was always noted as the source. As Bickerman wrote to Judah Goldin (1914-1998), one of the members of this personal team of academic advisors: "An Amhaarez like me needs the imprimatur of a hakam ${ }^{69}$." In sum, even if he never learned the necessary languages 
himself, Bickerman's universalized the study of Greco-Roman antiquity, but with a deliberately Jewish tendency.

In keeping with the complex nature of his identity, Bickerman's way of dealing with the mystical turn so popular in his time also had a distinctive character. Norden's remarks on mysticism were noted above, page 108. From another vantage point, Bickerman's St. Petersburg teacher, Rostovtzeff, had warned that the contemporary outburst of mysticism was not something desirable, as it might: "Work the end of our proud civilization", much as mysticism had contributed to the undoing of what was best in the ancient world. Rostovtzeff was concerned that: "Mystic aspirations in their higher and lower aspects are coming up afresh, especially among those people who learned a bitter lesson in the turmoils of revolution led by the materialistic spirit of socialist teachings ${ }^{70}$." Socialism, according to Rostovtzeff, was fomenting mysticism, and the latter might undo the best in the modern civilization, as it had done in antiquity. As Bickerman was staunchly anti-communist throughout his life ${ }^{71}$, he might have found Rostovtzeff's attitude very congenial.

Bickerman's more elaborate answer to the challenge of mysticism was an explicit and defiant historicism ${ }^{72}$. As he wrote, in the Preface to The Maccabees, completed in 1947, he had worked hard to turn himself into a contemporary of the ancient Maccabees rather than understand them in contemporary terms, for example, to turn them into the patrons of Zionist athletic clubs. He had turned the evidence over and over again with infinite patience, seeking to restore the people of the past as they lived and worked in their own environment. His goal was to write objective history, to be a contemporary of the Maccabees, and not to make a point about his own times via an analysis of the Maccabees ${ }^{73}$. When his student at Columbia University, Leo Raditsa (1936-2001), noted that Bickerman once seemed to be veering too close to the "Crocean heresy", that all history was simply a reflection of the present in which the historian lived, Bickerman insisted that this was not the case. Bickerman re-stated his belief in positivism and insisted that the concessions he had made to Crocean relativism in the draft essay Raditsa had seen were minor, insignificant, and only on the fringes. Bickerman explained that he still believed that the historian's task was: "To tell us what really happened in the past ${ }^{74}$."

At the same time, Bickerman turned to the rationalist heroes of the enlightenment, to the philosophes, as his source of inspiration. None of this mystical or theological mumbo-jumbo for him. He would serve up a straight dose of reason, with all its devastating consequences for those who adhered to a naïve or tendentious faith. Bickerman was drawn to the rationalism of Montesquieu (1689-1755), the critical reading of the Bible by English deists, such as Henry Dodwell (1641-1711) and Anthony Collins (1676-1729), and the anti-clericalism of Voltaire (1694-1778) $)^{75}$. In class, he claimed that his wide reading made him the most qualified faculty member at Columbia to teach French Intellectual History of the $18^{\text {th }}$ century, or American History of the Colonial and Revolutionary Eras, to elaborate the ways in which the "Founding Fathers" were disciples of the philosophes. There are numerous slips of paper in the Bickerman Archive at the Jewish Theological Seminary with notes on the philosophes ${ }^{76}$, and references to the philosophes are scattered throughout Bickerman's publications. For Bickerman, the giants of rational enlightened thought, the philosophes, could serve as a cure to the ills of modern irrationality. 
The ways in which Lewy fits into the argument of this paper are trickier to determine. In the Lebenslauf of his Berlin dissertation, Lewy noted his obligation to several teachers, but Norden took pride of place:

Vornehmlich fühle ich mich jedoch Eduard Norden zu Dank verpflichtet, der durch seine Lehre und Forschung meiner Beschäftigung mit den grossen Problemen des östlichen Hellenismus Methode und Ziel gegeben hat ${ }^{77}$.

However, since Lewy died so young, he did not live to elaborate the details and longer range goals of his scholarly agenda, so that the picture is incomplete. I therefore propose to return to Scholem's eulogy. After the general remarks about the Georgekreis quoted above, Scholem turned to Lewy. Scholem and Lewy were very close friends in Jerusalem, so he was an appropriate choice to eulogize Lewy ${ }^{78}$. They were among the six members of the pilegesh group that met regularly on Saturday afternoons to discuss matters of mutual interest, Jewish mysticism in particular. Pilegesh, in Hebrew, was an acronym for the names of the members, all scholars of the highest distinction: Hans J. Polotzki (1905-1991), Hans Jonas (1903-1993) ${ }^{79}$, Lewy, George Lichtheim (1912-1973, at whose home the group met), Scholem, and Samuel Sambursky (1900-1990) ${ }^{80}$. Since pilegesh means "concubine" the name was an explicit ironic acknowledgement that there was something not quite legitimate about what these men were doing together ${ }^{81}$.

Scholem framed his remarks in memory of Lewy in terms of the Rabbinic traditions about the four sages who entered pardes, that is engaged in esoteric philosophy (thag. 2.3, 381, Lieberman, and parallels). Three were harmed by whatever they saw: they "looked ${ }^{82 "}$, but the results were disastrous in one way or other. Only R. Akiba went up in peace and went down in peace. Unlike the three others, R. Akiba apparently "looked", but whatever he saw had no deleterious effect on him. According to Scholem,

George the poet and seer had enormous influence in the circles of young Zionists, especially during the critical years when Lewy's character was formed, in the early 1920s. Much of the special atmosphere of the circle around George penetrated into youth movements that admired George. When (George and his followers) raised the banner of the nuova scienza, the new path in academic life, these slogans found attentive ears among young Jews as well... As a result of his psychological bent, and his aesthetic and poetic sensibilities, Lewy should have been one of those who turned in the direction of imagination. However, his penetrating critical eye suspected the demonic forces hidden there. Lewy was loyal to George's lyrical poetry, but turned his back on the ideology of the George school. He "looked into" the profundities of the aristocratic symbolic world, and decided against it.

Lewy "looked" and withdrew. He detested the supposed syntheses of those who possessed the modern holy spirit, and instead elected a life of intensive work and tireless analysis. With a clear mind, he chose the most demanding methods of research championed by the sage Eduard Norden, who remained au-dessus de la mêlée, above the polemic of the different schools ${ }^{83}$. However, the fear of the seduction of the intuitive science that he had rejected remained engraved in Lewy's heart. As a result, he always carefully investigated the claims of intuition, both his and that of others, and considered them suspect. Accordingly, he matured before his time. Eighteen years ago (i.e. in 1927), when I met him for the first time, he already knew the direction his life would take, and his academic character was set no less than his personal character.

And yet, for Lewy, the sun never set on the world of intuition. I believe that it was not an accident that Lewy chose to study topics connected with the world of intuition. Religious literature and questions concerning the history of religion in 
late antiquity drew his attention and occupied him all his years. This literature demands great devotion, preparation, and exact analysis if one wants to reach firm conclusions concerning the questions it raises. Hellenistic religious mysticism, from Philo of Alexandria to the last of the Neo-Platonists, Proclus in particular, was at the heart of Lewy's work all the years I knew him. This was a place for a fruitful combination between Lewy's most unusual abilities and the deepest academic issues with far-reaching consequences... This research demanded exacting and profound ability at analysis, not only in order to appreciate the significance of religious ideas and symbols, but also to grasp the connections - often hidden from the eye - that open the path to a true understanding of ideas. Questions such as the path that leads from Wisdom, as in Proverbs, to Eastern-Greek gnosis aroused Lewy's interest to the highest degree. The philologist in him found the thread of Ariadne that runs through the labyrinth of syncretistic Hellenism in the history of terms and terminology. He knew well that the history of religion depends even more than the history of philosophy on the history of words and images ${ }^{84}$.

To draw the conclusion from Scholem's analysis, in the terms of this article, Lewy remained loyal to a mystical vision, yet knew how to draw out its sting and potentially harmful consequences, by studying the history of mysticism with the help of the philological tools learned from Norden, "the history of words and images", what Bickerman called "nitpicking" philological analysis of terms and forms in his portrait of Norden cited above ${ }^{85}$. Appropriately, Scholem concluded his remarks in memory of Lewy by citing the comment of Fustel de Coulanges that Lewy inscribed on one of his works: Le devoir de l'historien: une vie d'analyse pour une heure de synthèse. Scholem lamented the fact that Lewy had devoted his whole life to analysis, but because his life was so short did not have the privilege of arriving at the final moment of concluding synthesis for which he strived and at which he almost arrived. "The song of Lewy's life was cut off in the middle ${ }^{86}$."

In order to prepare himself for this task, Lewy was no vagabond, dependent on the help of others to study material in languages he did not control. Unlike Norden and Bickerman, Lewy learned the necessary languages himself - Hebrew, Aramaic, Syriac, Arabic, and Armenian at the University in Berlin and in the Hochschule für die Wissenschaft des Judentums ${ }^{87}$. Even Norden appreciated the significance of Lewy's efforts, as is clear from the letter he wrote on July 14, 1933 cited above.

As an expression of his own academic commitments, stressing the need not to remain a vagabond, but to learn the languages of the East and their literatures oneself, Lewy urged Bickerman to learn Hebrew. He wrote inviting Bickerman to join the editorial board of a new journal on Jewish Hellenism that he intended to found:

We are fostering a plan for which we need your assistance...: to start a journal dedicated exclusively to the research in Jewish Hellenism, both from the Greek and Jewish side... The task and the aim of the journal need no explanation: there does not exist any organ in any country which serves to this special purpose... Besides, the research in Jewish Hellenism is badly hampered by the fact that both Christian theologians and Jewish feuillitonists regard it as their battlefield. I think the time has arrived to reclaim it from both sides for a sound and unbiased criticism. As name for this journal I should propose: YEPHET, according to the verse in Gen. ix. 27: "God enlarge Japhet, and let him dwell in the tents of Shem ${ }^{88}$."

Yet, at the same time, Lewy felt obliged to remind Bickerman:

it would demand from you one effort: to learn modern Hebrew in order to understand the articles published. But I think, generally, that you can no longer avoid this effort, and I am sure that it will be worth while from many regards ${ }^{89}$. 

than Norden's or Bickerman's. Where Lewy and Bickerman were closer to each other
then was was in their approach to universal history, to including the Jews as part of the story of the ancient world: Lewy, as already noted above, chose to focus on gathering the sources discussing the Jews and Judaism in Greco-Roman literature. He had a major project, already underway in his Berlin years, and financed by the Notgemeinschaft der Deutschen Wissenschaft ${ }^{90}$, devoted to this effort. According to Scholem, from his earliest days as a student in Berlin until his last days in Jerusalem, Lewy regularly lamented the walls separating Jewish Studies from the world of general knowledge. He saw these boundaries as artificial, and never stopped blaming fellow scholars of Judaica for having erected them themselves. He dreamt of a fruitful union between philology, as he understood it, and Talmudic research and study of the Jewish tradition. He spoke often among his friends on the mutual obligations of both sides and of his great disappointment that too many specialists in Jewish Studies did not understand their task and role ${ }^{91}$. If Lewy had been privileged to live a longer life, Norden's universal vision of the world of antiquity would have yielded a singular contribution of the highest caliber.

\section{IV}

The chain of scholarly tradition in which Norden was an important link had at least two more links coming off Norden's place in that chain - Bickerman and Lewy. These new links would not have taken the form they did without their connection to Norden, but each took the Norden heritage in a somewhat different direction - one scholar turning to the heroes of rationalism, the philosophes, the other to the history of mysticism. One troubled to learn as many Eastern languages as possible, the other resisted the suggestions to learn Hebrew, relying on the help of friends. These differences, however, were minor in comparison to the lessons both Bickerman and Lewy learned from Norden, with their mutual concern with words, formulas and their history (in diplomatic texts for Bickerman, in mystical works for Lewy), and to write universal history. Whatever personal similarities and differences there may have been between Bickerman and Lewy, the intellectual basis for their friendship went back to their years with Norden in Berlin.

40 Chains of tradition also come to an end. Circumstances are such that it is now almost impossible to add further links to the Norden-Bickerman-Lewy chain. Both Bickerman and Lewy were beneficiaries of an academic training varied, rich, high in level, but also nearly impossible to duplicate anytime or anywhere since. Bickerman founded no "school92"; his posthumous work, The Jews in the Greek Age (1988), the cumulative result of more than forty years of investigation and writing, has had little impact on subsequent scholarship ${ }^{93}$. Lewy, along with other scholars trained in Berlin, through their teaching at the Hebrew University helped shape the study of Classics there and in Israel as a whole ${ }^{94}$, but Lewy's life was too short.

41 There is a well known story about the conversation between the great mathematician at Göttingen, David Hilbert (1862-1943), and Bernhard Rust, the Nazi minister of Education, when Rust asked Hilbert about the state of mathematics at Göttingen, now 
that it had been purged of its Jewish influence. Hilbert responded: "Mathematics in Göttingen? There is really none any more ${ }^{95}$." John Glucker has written much the same for Classics in Germany:

Ein Jude, der Arzt, Richter, deutscher Schriftsteller, Komponist oder Schauspieler geworden war, der war eigentlich assimiliert. Aber ein armer klassischer Philologe? Man musste ganz meschugge sein um sich mit diesen toten Sprachen zu beschäftigen. Und doch, wer die Rolle der Juden in der Entwicklung der klassischen Philologie studiert, der kann nur feststellen, dass ohne Gelehrte wie... - und das sind nur einige Beispiele aus einer Liste von etwa 120 Namen - die deutsche klassische Philologie im neunzehnten und zwanzigsten Jahrhundert eines wesentlichen Teils ihrer Grösse und Tiefe beraubt wäre ${ }^{96}$.

The reason for this decline was not that Jews are possessed of some special genius that would be a perverse inversion of Nazi racism, one as equally objectionable as the other. Rather, learning at the highest level requires freedom for all, and cannot flourish long under circumstances of persecution or extermination. So, the world of NordenBickerman-Lewy is gone. We can only respond by applying Scholem's concluding remark on Lewy's short life to the Norden-Bickerman-Lewy chain as a whole: we can marvel at their achievements, appreciate their singular contributions, but also lament the fact that the song of their collective academic and intellectual life was cut so short.

\section{NOTES}

*. This article is a revised version of a paper presented at the Institut für Klassische Philologie of the Humboldt University, Berlin, on January 27, 2010. I thank my Berlin host, Wolfgang Rösler, for the opportunity to present these ideas and to benefit from comments and criticism. I am also indebted to Hubert Cancik and Hildegard Cancik-Lindemaier of Berlin, who facilitated the invitation to speak there. Their research on the history of German Classical scholarship intersects with mine, and they have been enthusiastic supporters and collaborators in my efforts over many years. This paper should be read in conjunction with H. CANCIK and H.CANCIKLINDEMAIER, "Berliner Konstellationenen am Ende der Weimarer Republik. Eduard Norden und die Altertumswissenschaft in Jerusalem”, Anabases 12 (2010), p. 69-91.

1. In this paper, I elaborate and extend A.I. BAUMGARTEN, Elias Bickerman as a Historian of the Jews: A Twentieth Century Tale, Tübingen, 2010. The references to archival documents in this paper follow the abbreviations there, p. 325-332.

For a brief summary of the details of Elias Bickerman's life as background to this article, see A.I. BAUMGARTEN, "Elias Bickerman on the Hellenizing Reformers: A Case Study of an unconvincing case", Jewish Quarterly Review 97 (2007), p. 149-151. See also BAUMGARTEN, Elias Bickerman, p. 18-24.

2. Rostovtzeff to Johnson, October 4, 1940, Rostovtzeff Archive: G. BONGARD-LEVIN, Skifskii Roman, Moscow, 1997, \#9. For an extended discussion of Bickerman's complex attitudes towards his own past see BAUMGARTEN, Elias Bickerman, p. 25-49.

3. Bickerman to Lewy, February 15, 1943, Lewy Archive.

4. Bickerman to Mrs. Lewy, September 4, 1945, Lewy Archive.

5. E.J. BICKERMAN, "Ritualmord und Eselkult", Studies in Jewish and Christian History, Part Two, Leiden, 1980, p. 238, n. 55=Studies in Jewish and Christian History, A New Edition in English, including The God of the Maccabees, Leiden, 2007, p. 509, n. 55. 
6. E.J. BICKERMAN, Der Gott der Makkabäer, Untersuchungen über Sinn und Ursprung der makkabäischen Erhebung, Berlin, 1937, p. 4.

7. Schocken Archive, Wiss. Verlag, note of June 20, 1936, listing Manuskripte in Arbeit.

8. Bickerman to Mrs. Lewy, November 17, 1946, Lewy Archive. In the end, the plan for a work of this sort was realized by M. STERN, Greek and Latin Authors on Jews and Judaism, Jerusalem, 1974-1984. Professor Daniel Schwartz of the Hebrew University informs me that he owns Lewy's personal copy of Reinach, with notes in the margin in Lewy's hand. See also the discussion below, at n. 90 .

9. Bickerman to Hengel, November 14, 1976, Hengel Files.

10. See further BAUMGARTEN, Elias Bickerman, p. 86-111.

11. HU Archive, Phil Fak. 689, 28.

12. HU Archive, Phil. Fak. 689, 29.

13. HU Archive, Phil. Fak. 39, 26.

14. HU Archive, Phil. Fak. 39, 399.

15. In Latin, Norden gave Lewy the mark sehr gut, HU Archive, Phil. Fak. 689, 29.

16. On another occasion, E. NORDEN, "Der Genesiszitat in der Schrift vom Erhaben", Kleine Schriften zum klassischen Altertum, Berlin, 1966, p. 307, Norden called Philo the: Hauptrerepräsentanten des hellenisierten, also denaturierten Judentums, eines nicht eben sehr erfreulichen Erscheinungstyps.

17. Given the undistinguished passing mark Lewy's dissertation received, Norden apparently felt it better not to mention the formal grade given.

18. Both Wilamowitz (1848-1931) and Meyer (1855-1930) were no longer alive in 1933, when Norden wrote this letter.

19. G. scholem, "Hans Lewy", in H. Lewy, 1901-1945, Memorial Addresses Delivered at the Hebrew University by J.L.Magnes, M. Schwabe, G. Scholem, Jerusalem, 1946, p. 12, [Hebrew]. Lewy Archive; reprinted as G. SCHOLEM, Devarim Bego (Explications and Implications, Writings on Jewish Heritage and Renaissance), Tel Aviv, 1975, p. 479 [Hebrew].

Scholem noted that Lewy had a dry but incisive sense of humor. This is confirmed by Lewy's appearance in S.Y. AGNON, Shira, translated from the Hebrew by Z. SHAPIRO, New York, 1989, p. 341. Many of the characters in the novel are fictionalized versions of well known figures in the Jerusalem academic world of Agnon's day. Lewy is one of the few who appears with his real name. One of the members of the collective settlement where Herbst's daughter lives remembers a lecture by Lewy in which Lewy told a memorable joke: Lewy discussed St. Jerome's Jewish teacher, adding that in a particular case - as a result of misinformation obtained from that teacher - "Saint Jerome had misinterpreted a particular biblical verse, and that, for Jerome, that teacher was a poor investment."

20. Presumably this story took place before Lewy's move to Jerusalem in 1933 and before Bickerman's marriage in Paris, on July 28, 1936.

21. This is the story as I heard it from Martin Hengel, a slightly improved and more pointed version than as told by B. BAR-KOCHVA, "E. Bickermann's Research of the Second Temple Period", Cathedra 23 (1982), p. 8, [Hebrew]. In consideration of the special nature of oral memories, my own included, I print all oral recollections in italics. On Bickerman as an enfant terrible see also below, n. 67 .

22. For Lewy's opposition to communism see SCHOLEM, "Hans Lewy", p. 18=Devarim bego, p. 485; for Bickerman see BAUMGARTEN, "Elias Bickerman on the Hellenizing Reformers", p. 169-179; BAUMGARTEN, Elias Bickerman, p. 262-264.

Daniel Pasmanik (1869-1930), once considered an important Zionist leader, lost his position and friends in Zionist circles when he was active in Joseph Bikerman's "Patriotic Union of Russian Jews Abroad", and supported the Whites in the Russian Civil War. See further J.B. sch(ECHTMAN)., s.v. "Pasmanik, Daniel”, Encyclopedia Judaica, XIII, 1972, col. 160-161. 
23. Like many Russians who came to the west, the $B i(c) k e r m a n(n) s$ spelled their last name at least three different ways over the course of their lives. Elias was Bickermann during his German years, Bikerman in Paris, and Bickerman in the USA. His father and brother, Joseph and Jacob, also experimented with various spellings, but eventually settled on Bikerman.

For a summary of Joseph Bikerman's anti-Zionist views see BAUMGARTEN, "Elias Bickerman", p. 178; BAUMGARTEN, Elias Bickerman, p. 53-55.

24. For the brief romance between Elias Bickerman and the Hebrew University in 1935-36, in which Lewy presumably played a role, although he is never mentioned in the extant documents, see BAUMGARTEN, Elias Bickerman, p. 125-127.

25. D. SORKIN, "Wilhelm von Humboldt: The Theory and Practice of Self-Formation (Bildung), 1791-1810", Journal of the History of Ideas 44 (1983), p. 55-73. According to G. MOSSE, "Gershom Scholem as a German Jew", Modern Judaism 10 (1990), p. 123-124, this Bildung was supposed to develop self-cultivation, but the latter was not meant to be chaotic but controlled through a study of the ancients, that is, the Greeks whose language itself was supposed to discipline and energize the mind (emphasis mine). Thus informed, reason must secure its domination over the senses and activate man's ethical nature.

26. P. GAY, Weimar Culture: The Outsider as Insider, New York, 2001, p. 47. See further R. NORTON, Stefan George and his Circle - Secret Germany, Ithaca, 2002.

27. NORTON, Stefan George, p. 397, 409, 429-430, 446-456.

28. See Gérardy's Widmung an Stefan George, originally published in 1894, as reprinted in H. RASCHEL, Das Nietzsche-Bild im Georgekreis, Berlin/New York, 1984, p. 30, n. 63.

29. As cited in U. RAULFF, Kreis ohne Meister - Stefan Georges Nachleben, Munich, 2009, p. 324.

30. See A. BOUREAU, Kantorowicz, Stories of a Historian, translated by S.G. NICHOLS and G.M. SPIEGEL, Baltimore, 2001, p. 1.

31. RAULFF, Kreis ohne Meister, p. 108-109. See further E.J. BICKERMAN, "Das leere Grab", Studies in Jewish and Christian History, Part Three, Leiden, 1986, p. 70-81=Studies in Jewish and Christian History A New Edition in English, p. 712-725; E.J. BICKERMAN, "Die römische Kaisarapotheose", Religions and Politics in the Hellenistic and Roman Periods, Como, 1985, p. 1-36.

32. For the clash between George and his devotees and classicists see further L.A. TRITLE, "Plutarch in Germany: The Stefan George Kreis", International Journal of the Classical Tradition 1, 3 (1995), p. 109-121, esp. p.120-121, n. 62. See also U.K. GolDSMITH, "Wilamowitz and the ‘Georgekreis': New Documents”, in H.E. BARNES, W.M. CALDER III, H. SCHMIDT (eds.), Studies in Comparison, New York, 1989, p. 125-162.

One way Wilamowitz responded to the disdain of George and his disciples was by concocting a spoof of George's poetry and circulating it among friends. See U.K. GOLDSMITH, "Wilamowitz as Parodist of Stefan George", Studies in Comparison, p. 163-172. Wilamowitz ended his parody by referring to George's impotence, a not too oblique reference to a subject that was taboo at the time, the homoerotic nature of relations between George and his disciples. See further NORTON, Stefan George, p. 438-439.

33. Two other eulogies were delivered at that memorial meeting, one by Judah Magnes (1877-1948), President of the University, and the other by Moshe Schwabe (1889-1956), Lewy's senior colleague in Classics, and a fellow student of the same masters in Berlin with whom Lewy studied. Perhaps the only notable point in Magnes' remarks was a comment on Lewy's shy and diffident personality, p. 5, also recorded by Scholem, above, n. 19. I have translated and analyzed Schwabe's significant comments on the Berlin academic scene and Lewy in A.I. BAUMGARTEN, "Eduard Norden and his Students: A Contribution to a Portrait, Based on Three Archival Finds", Scripta Classica Israelica 25 (2006), p. 131-139. On Schwabe himself see CANCIK and CANCIK-LINDEMAIER, “Berliner Konstellationen", p. 84-85.

34. Scholem was echoing Dan 5:26. 
35. George himself described the mindset of the typical academic researcher as focused on: wie mache ich aus nichts etwas, RASCHEL, Das Nietzsche-Bild im Georgekreis, p. 84. See further below, n. 38 . 36. The miserable rate payers, in intellectual terms, the academic serfs.

37. Scholem exaggerated somewhat. In at least one case, that of Kurt Hildebrandt, Wilamowitz fought hard (but unsuccessfully) to make sure that Hildebrandt was not appointed at Berlin. In 1910, Hildebrandt published an article sharply critical of Wilamowitz, calling him a vulgar popularizer, who had missed the real meaning of the Greek classics. Hildebrandt then had the temerity to send a copy of that article to Wilamowitz. A decade and a half later, Hildebrandt applied for Habilitation at Berlin. This request was discussed by three committees at six faculty meetings, from January 21, 1926 to March 1, 1928 (HU Archive, Phil. Fak. 551, 182; 551, 317; 552, $45 ; 552,58 ; 552,76 ; 552,87)$. Wilamowitz succeeded in getting Hildebrandt's Habilitation turned down by a vote of 17 in favor, 9 against. As $3 / 4$ in favor were required, if three more faculty members had voted in favor, Hildebrandt would have proceeded to the oral. However, Minister Becker (an admirer of Stefan George) then intervened on Hildebrandt's behalf and indicated his intention to appoint Hildebrandt to a special position to teach Natural Philosophy. The minister persisted, and eventually the faculty had no choice but to accept the inevitable, limiting itself to "politely" asking the minister to explain the reasons why he had made this appointment, despite their objections. In the end, Wilamowitz succeeded in getting Hildebrandt's Habilitation scuttled by a few votes, but lost the war, since Hildebrandt was appointed in spite of objections by the Faculty. On the Hildebrandt affair in Berlin see also R. KOLK, Literarische Gruppenbildung: Am Beispiel des Georgekreises 1890-1945, Tübingen, 1998, p. 362-368.

Hildebrandt's troubles continued in the next phase of his academic career, when he was a candidate for a professorship at Kiel in 1933/34. Even Hildebrandt's local supporters agreed that he was a boring teacher, who would not attract many students, but they hoped that in light of his originality he might appeal to the best and brightest. They stressed the importance of his intimate connections with the Georgekreis and the enthusiastic letter supporting Hildebrandt's candidacy by Martin Heidegger. The opposition to Hildebrandt was led by Richard Harder (1896-1957), who was a pupil of Jaeger's, the latter a student of Wilamowitz and his successor in Berlin. Harder insisted that: Hildebrandt's knowledge of Greek was weak, that he had been refused Habilitation at Berlin, that he was a dilettante and a plagiarist, and that he had once written in support of miscegenation between Germans and Jews. When all these arguments failed, Harder charged that Hildebrandt's wife was Jewish. In the end, Hildebrandt was called to a professorship at Kiel at the end of April 1934. КоLK, Literarische Gruppenbildung, p. 527-529, and the documents cited there, p. 621-628.

38. In general, George and his disciples were disdainful of all Wissenschaft. George's pronouncements included: Von mir aus führt kein Weg zur Wissenschaft, or Die Wissenschaft ist Schwindel, RASCHEL, Das Nietzsche-Bild im Georgekreis, p. 84, and 87; KOLK, Literarische Gruppenbildung, p. 368-375.

Nevertheless, several Georgeans (Kantorowicz or Gundolf, for example) had distinguished university careers and were held in high esteem in academic circles. See further NORTON, Stefan George, p. 437-442 and 457-471; KOLK, Literarische Gruppenbildung, p. 384-416.

Even Hildebrandt's initial attack on Wilamowitz evoked a favorable response from any number of Berlin professors, NORTON, Stefan George, p. 444. Max Weber, easily one of the brightest stars in the German academic world, had a deep interest in George and the two met when George was in Heidelberg, even though Weber ultimately rejected George and his disciples because of the demand for personal sovereignty and absolute service, i.e. the sacrifice of individual identity in devotion to the Master, the sectarian nature of the Georgekreis, ibid., p. 475-480; RASCHEL, Das Nietzsche-Bild im Georgekreis, p. 85. Minister Becker, who insisted on appointing Hildebrandt in 
Berlin, was not the only admirer of George in the academic world. One must remember that a majority of the Berlin faculty members voted in favor of accepting his Habilitation, above, n. 37.

39. Nietzsche had written: Die stillsten Worte sind es welche den Sturm bringen. Gedanken, die mit Taubenfüßen kommen, lenken die Welt. F. NIETZSCHE, Also Sprach Zarathustra, Part II, "Die stillste Stunde”, in G. Colli and M. MONTINARI (eds.), Nietzsche's Werke, Kritische Gesamtausgabe, Berlin, 1968, vol. VI, Part I, p. 185.

40. The choice between Nietzsche and Wilamowitz went back to the latter's attack on The Birth of Tragedy as contrary to the basic tenets of scientific method and as a rape of historical facts and all historical method. See further M.S. SILK \& J.P. STERN, Nietzsche on Tragedy, Cambridge/New York, 1981, p. 90-106; KARLAUF, Stefan George, p. 440-444; KOLK, Literarische Gruppenbildung, p. 354-362.

The dispute became nasty and personal. As summarized by NORTON, Stefan George, p. 438-439, Nietzsche referred to Wilamowitz as "Wilam ohne Witz (Wilam without Wit)", or as "Wilamops (Wilam the pug, or Wilam the fatty)". These abuses were taken up by George and his followers, who saw themselves as avenging Nietzsche. George also called Willamowitz "Wilamops". According to E. LANDMANN, Gespräche mit Stefan George, Düsseldorf, 1963, p. 95, George wondered how Wilamowitz, who had proven that he had a vile and ugly soul, could be so physically attractive. George solved this paradox with the theory that Wilamowitz excreted all that was base and mean within him, all of the offal into his books, and what remained was the pure type. Wilamowitz' books were latrine buckets. On Wilamowitz' ad hominem reply to George see above, n. 32. On the nature of the relationship between Nietzsche and George see the detailed analysis in RASCHEL, Das Nietzsche-Bild im Georgekreis, esp. p. 1-4, 27, 75-78, 81, and 84-85. Raschel summarizes his discussion, ibid., p. 91, by concluding that for the Georgeans Nietzsche was a forerunner, come to announce the imminent arrival of someone greater than he, George; Nietzsche for them was John the Baptist, while George was Christ.

41. SCHOLEM, "Hans Lewy", p. 15-16=Devarim Bego, p. 483-484. Translation mine.

42. See RAULFF, Kreis ohne Meister, p. 67, based on G. SCHOLEM, Briefe an Werner Kraft, Frankfurt, 1986, p. 30. In general, as RAULFF, Kreis ohne Meister, p. 493 notes, Scholem's correspondence with Kraft and Michael Landmann shows Scholem's lively interest in the ideas current in the Georgekreis.

As one indication of Scholem's fascination with the Georgekreis, he imagined that he would create a Jewish version of that circle of devotees, with himself in the central role. See S. ASCHHEIM, Scholem, Arendt, Klemperer, Intimate Chronicles in Turbulent Times, Bloomington, 2001, p. 19. On Scholem, see further below, n. 85 .

43. SCHOLEM, "Hans Lewy", p. 17=Devarim Bego, p. 484. As noted by KARLAUF, Stefan George, p. 615, for many of George's devotees, it was very difficult, as Ernst Morwitz (1887-1971) wrote: die Texte George's zu lesen und nicht zu glauben, was in Deutschland jetzt geschehe, sei das, was George gewollt habe.

Despite repeated requests, George himself was sphinx like in his unwillingness to state categorically whether he approved or not of the way in which some of his devotees understood his teachings as supportive of Nazi Germany. See NORTON, Stefan George, p. 725-736; KARLAUf, Stefan George, p. 610-637; RAULFF, Kreis ohne Meister, p. 56-83. However, the regime ultimately disavowed him: its spokesmen denounced him as half-Jewish (his real name was supposedly Abeles), and his circle was full of Jews, NORTON, Stefan George, p. 743-744; RAULFF, Kreis ohne Meister, p. 87-94.

44. E. NORDEN, “Worte des Gedächtnisses an Ulrich von Wilamowitz-Moellendorff”, Kleine Schriften, p. 665. See further W.M. CALDER III, “'Aquila in Nubibus' Ulrich von Wilamowitz-Moellendorff in his Letters to Eduard Norden (1893-1931)”, in B. KYTZLER, K. RUDOLPH \& J. RÜPKE (eds.), Eduard Norden (1868-1941), ein deutscher Gelehrter jüdischer Herkunft, Stuttgart, 1994, p. 173-190.

45. NORDEN, "Worte des Gedächtnisses an Ulrich von Wilamowitz-Moellendorff", p. 665. On Wilamowitz's willingness to change his mind and revise previously held views see F. SOLMSEN, "Wilamowitz in His Last Ten Years", Greek, Roman and Byzantine Studies 20 (1979), p. 113. See also 
BAUMGARTEN, Elias Bickerman, p. 97-98.

Even the slightest chance that Norden was unaware of the tensions between Wilamowitz and the Georgekreis is ruled out by the fact that most of the "trouble" concerning Hildebrandt's Habilitation at Berlin (above, n. 37) took place during 1927-1928, the year Norden was rector. As occupant of that office, he must have been deeply involved in the meetings, correspondence with Minister Becker, and the organization of the faculty's opposition to Hildebrandt.

46. See above, n. 40. See also RASCHEL, Das Nietzsche-Bild im Georgekreis, p. 73-84, 88. Both the Georgekreis and the philologists preached for the union of Greek and German values. The difference was that for George and his followers, the line to the Greeks went back to Nietzsche and from him to Hölderlin. See RAULFF, Kreis ohne Meister, p. 256-257.

47. NORDEN, "Worte des Gedächtnisses an Ulrich von Wilamowitz-Moellendorff", p. 667.

48. BAUMGARTEN, "Eduard Norden", p. 121-139.

49. BAUMGARTEN, "Eduard Norden", p. 128.

50. GAY, Weimar Culture, p. 96.

51. E. NORDEN, “Logos und Rhythmus", Kleine Schriften, p. 549.

52. BAUMGARTEN, "Eduard Norden", p. 129.

53. M. RostovtzefF, s.v. "Eduard Meyer (1855-1930)", in E. SEligman and A. JOHNSon (eds.), Encyclopedia of the Social Sciences, X, 1933, p. 402. See also F. PARENTE, "Die Entstehung des Judentums: Persien, Achämeniden und das Judentum in der Interpretation von Eduard Meyer", in W.M. CALDER III - A. DEMANDT (eds.), Eduard Meyer: Leben und Leistung eines Universalhistorikers, Leiden/ New York, 1990, p. 329-343.

54. Norden conceded, for example, that his control of Hebrew was not that extensive, "Logos und Rhythmus", p. 541. See also E. NORDEN, Agnostos Theos, Stuttgart/Leipzig, 1913, p. 205-206.

55. For example, in citing the Icelandic text, Norden relied on the translation of the local expert in Nordic philology.

56. E. NORDEN, “Heldenehrungen”, Kleine Schriften, p. 552.

57. E. NORDEN, Die Geburt des Kindes, Leipzig/Berlin, 1924, p. 4. See further J.E. BAUER, “ Wahrheitsliebe und Judentum"», in KYTZLER et al., Eduard Norden (1868-1941), p. 221-222. One wonders how Norden would have reacted if someone adopted the same vagabond approach to Vergil, a Latin author about whom Norden wrote at length.

58. GAY, Weimar Culure, p. 93.

59. See J. GLUCKER, "Juden in der deutschen klassischen Philologie", in W. GRAB (ed.), Juden in der deutschen Wissenschaft, Tel Aviv, 1986, p. 95. Despite this, when Norden's friends collected a significant amount of money on the occasion of his sixtieth birthday, it was used to establish a fund that would support students and young scholars of all faiths: bestimmt für Studenten und jüngere Gelehrte jeder Confession. This inclusiveness would be of special benefit to the many young Jewish students and scholars then at Berlin. See below, at n. 96 and CANCIK and CANCIK-LINDEMAIER, “Berliner Konstellationen", p. 79-81, 90-91.

60. On Norden's politics, an especially sensitive topic during the year he was rector, 1927-1928, and his attitude towards German identity see CANCIK and CANCIK-LINDEMAIER, "Berliner Konstellationen", p. 72-74.

61. See BAUER, "Wahrheitsliebe und Judentum", p. 223.

62. See F.W. LENZ, "Erinnerungen an Eduard Norden", Antike und Abendland 7 (1958), p. 170-171; B. KYTZLER, "Eduard Norden", in W.W. BRIGGS and W.M. CALDER III (eds.), Classical Scholarship, A Biographical Encyclopedia, New York, 1990, p.341; W.A. SCHRÖDER, Der Altertumswissenschaftler Eduard Norden (1868-1941) Das Schicksal eines deutschen Gelehrten jüdischer Abkunft, Hildesheim, 1999, p. 33-49; cf. BAUER, "Wahrheitsliebe und Judentum", p. 208 for a discussion of possible reasons to object to Lenz' characterisation of Norden's attitude towards Judaism. 
63. While Norden's parents were therefore nominally Jewish, they were not practicing Jews in any usual sense. They encouraged his conversion as a necessary condition for a career in the field of his choice, BAUER, "Wahrheitsliebe und Judentum", p. 207. Norden buried his mother in a Christian cemetery in Lichterfelde. See further CANCIK and CANCIK-LINDEMAIER, "Berliner Konstellationen", p. 71, n. 6.

64. Bickerman to Gabba, August 9, 1976, Gabba Archive. For Bickerman, being a Marxist was the kiss of death. He also believed in the autonomy of the study of the ancient past. No assistance from the social sciences was needed. See further BAUMGARTEN, Elias Bickerman, p. 154-156. All this came into play in Bickerman's comments on J.P. Vernant just cited: Vernant had three strikes against him: no universal history, Marxism, and the turn to the social sciences.

65. E. BICKERMAN, Das Edikt des Kaisers Caracalla in P. Giss. 40, Berlin, 1926, p. 39.

66. D. WASSERSTEIN, "Refugee Classicists in Britain after 1933", Scripta Classica Israelica 24 (2005), p. 229-247.

67. In general, Bickerman delighted in constructing an image of himself as an unconventional contrarian, unencumbered by the sort of limits that might restrict others, a daring enfant terrible. See further BAUMGARTEN, Elias Bickerman, p. 38-45, 183-184. Norden's vagabond attitude towards sources in languages he did not control would have posed no problem for Bickerman.

68. See Elias Bickerman's comments in his letter to Martin Hengel, noted above, p. 97. See also Jacob Bikerman's recollections, J. BIKERMAN, Two Bikermans: Autobiographies by Joseph and Jacob J. Bikerman, New York, 1976, p. 99: "In 1914 another relative often visited us. He was supposed to teach the two sons Hebrew. Unfortunately, the story of Eden was enacted again. Our garden had many apple trees, and the fruit was ripening when study hours came. The boys were tempted by the apples and could not concentrate on work."

69. Bickerman to Goldin, undated, but with postmark of November 1961, Judah Goldin Files.

70. M. RostovtzeFF, Mystic Italy, New York, 1927, p. 3-23, quotations, p. 22.

71. See above, n. 22.

72. See further D. MYERS, Resisting History - Historicism and its Discontents in German-Jewish Thought, Princeton, 2003.

73. E.J. BICKERMAN, The Maccabees, translated by M. HADAS, New York, 1947, p. 8.

74. Bickerman to Raditsa, November 23, 1973, Raditsa Archive.

75. See, for example, the discussion of Porphyry and his successors in understanding the second half of the book of Daniel, E.J. BICKERMAN, Four Strange Books of the Bible, New York, 1967, p. 131-135.

76. Bickerman Archive, Jewish Theological Seminary, box 3.

77. HU Archive, Phil. Fak. 689, 35.

78. See above, n. 33.

79. The most recent work on the life and work of Jonas, of which I am aware, is C. WIESE, The Life and Thought of Hans Jonas: Jewish Dimensions, translated by J. GROSSMAN and C. WIESE, Waltham, 2007.

80. See O. BAR-ON, Samuel Sambursky - Science Historian, PhD thesis, Tel Aviv University, 2001, [Hebrew].

81. See Gershom Scholem (1897-1982) A Commemorative Exhibition, Jerusalem, 1988, p. 37. See also N. ZADOFF, “'Mit Witz im Ernst und Ernst im Witz': der Jerusalemer PILEGESCH-Kreis”, Jüdischer Almanach (2004), p. 50-60.

82. Lewy had a small face, but with penetrating eyes and large eyeglasses. Scholem's eulogy has several metaphors alluding to looking and seeing, all referring back to this aspect of Lewy countenance. In addition, Scholem noted explicitly that Lewy seemed to "hide behind his large eyeglasses", scholem, "Hans Lewy", p. 12 = Devarim Bego, p. 479.

83. Norden was described by his contemporaries as avoiding polemics. See further BAUMGARTEN, "Eduard Norden", p. 125, n. 18, and p. 135.

84. SCHOLEM, "Hans Lewy", p. 17-18 = Devarim bego, p. 484-485. Translation, again mine. 
85. Much has been written about Scholem in recent years, and he is not the subject of this article, but one cannot help wonder the extent to which this description of Lewy is also autobiographical. Did Scholem also resolve the conflict between the attractions of mysticism and awareness of its dangers by historical-philological study of Jewish mysticism? The suggestion that there was an autobiographical component in Scholem's description of Lewy receives significant support from the autobiographical nature of Scholem's description of Lewy's interest in the Georgeans, as discussed above, esp. n. 42.

86. sCHOLEM, "Hans Lewy", p. 18 = Devarim bego, p. 486.

87. Lewy's Lebenslauf, Lewy Archive.

88. Lewy to Bickerman, September 15, 1944. Lewy Archive.

89. Ibid.

90. Lewy's report to the Notgemeinschaft on progress for the year from Spring 1927 to Spring 1928 is in the Lewy Archive.

91. SCHOLEM, "Hans Lewy", p. 18 = Devarim bego, p. 485-486.

92. See S. schwARTZ, s.v. "Bickerman, Elias Joseph", in J. GARRATY - M. CARnEs (eds.), American National Biography, II, 1999, p. 725.

93. BAUMGARTEN, Elias Bickerman, p. 276-277.

94. See CANCIK and CANCIK-LINDEMAIER, “Berliner Konstellationen”, p. 81-82.

95. C. REID, Hilbert, New York, 1996, p. 129.

96. GLUCKER, "Juden in der deutschen klassischen Philologie”, p. 96-97.

\section{ABSTRACTS}

This paper examines the friendship of Elias Bickerman (1897-1981) and Hans (Yohanan) Lewy (1901-1945), setting them in context as students of Eduard Norden (1868-1941) in Berlin. It focuses on the different ways in which Norden, Bickerman and Lewy met the challenges to Classical Studies in the Weimar era, in particular those that were dealt with by Stephan George and his disciples.

Cet article étudie l'amitié entre Elias Bickerman (1897-1981) et Hans (Yohanan) Lewy (1901-1945), replacés dans le contexte de leurs études auprès d'Eduard Norden (1868-1941), à Berlin. L'accent est mis sur les différentes voies selon lesquelles Norden, Bickerman et Lewy affrontèrent les défis relatifs aux études classiques à l'époque de Weimar, en particulier ceux qui étaient abordés par Stefan George et ses disciples.

\section{INDEX}

Mots-clés: Norden Eduard, Bickerman Elias, Lewy Hans (Yohanan), Scholem Gershom, George Stefan

Keywords: Norden Eduard, Bickerman Elias, Lewy Hans (Yohanan), Scholem Gershom, George Stefan 
AUTHOR

ALBERT I. BAUMGARTEN

Bar Ilan University

baumgaa@mail.biu.ac.il 